\title{
STRATEGI KOMUNIKASI PEMASARAN INTERAKTIF CIEWIE BATIK DALAM CUSTOMER ENGAGEMENT
}

\author{
Marsudi \\ Pascasarjana Komunikasi Fakultas Ilmu Komunikasi Universitas Persada Indonesia YAI \\ Jl. Diponegoro No. 74, Jakarta Pusat \\ Marsudikhang@yahoo.com
}

\begin{abstract}
This research eagers to analyse Ciewie Batik Interactive Marketing Communication Strategy in customer engagement. This research intends to show the meaningful of Ciewie Batik Interactive Marketing Communication Strategy in Business dealing. Research runs the qualitative descriptive method using documentation study and indepth interview. According to documentation study and indepth interview, can be concluded that Ciewie Batik Interactive Marketing Communication Strategy in dealing Business consist of : maximizing and intensified the Ciewie Batik Instagram Account, integrating the servicing customer process with Android Application, intensified customer question and complaint expressly, active in Facebook fanpage, dan keep on updating Ciewie Batik website including actively hire webreseller.
\end{abstract}

Penelitian ini ingin menganalisis Strategi komunikasi pemasaran Interaktif Ciewie Batik dalam customer engagement. Penelitian ini bertujuan untuk menunjukkan pemahaman tentang Strategi dan bentukbentuk komunikasi pemasaran Interaktif Ciewie Batik dalam melaksanakan bisnisnya. Penelitian ini menggunakan metode deskriptif kualitatif dengan studi melalui dokumentasi dan wawancara mendalam Berdasarkan hasil wawancara dan dokumentasi, dapat disimpulkan bahwa Strategi komunikasi pemasaran Interaktif yang dipergunakan Ciewie Batik dalam melaksanakan rutinitas bisnisnya meliputi : memaksimalkan serta mengintensifkan akun Instagram Ciewie Batik, mengintegrasikan proses pelayanan pelanggan dengan aplikasi Android, mengintensifkan layanan keluhan dan pertanyaan pelanggan yang express, aktif dalam Fanpage Facebook, dan senantiasa update di website Ciewie Batik termasuk aktif merekrut web-reseller.

Kata kunci: Komunikasi Pemasaran, Social Information Processing Theory, Strategi Komunikasi Interaktif, Customer Engagement, Ciewie Batik

\section{PENDAHULUAN}

Perkembangan teknologi informasi dan komunikasi Digital telah membawa pengaruh di semua aspek kehidupan manusia yang selain memudahkan kehidupan manusia juga membawa dampak bagi penggunanya. Semua dampak ini semakin menegaskan betapa viralnya pengaruh dan eksistensi teknologi informasi dan komunikasi di dunia saat ini.
E-Commerce dengan Komunikasi Interaktifnya merupakan salah satu instrumen teknologi informasi dan komunikasi kontemporer yang menjadi media online yang tidak asing lagi bagi semua orang di era ini. Selain karena berbagai informasi interaktif one-one maupun one-to-many yang bisa di peroleh (Riel, 2000), juga menjadi tempat berlangsungnya berbagai transaksi penjualan 
online khususnya di Onlineshop dewasa ini . Onlineshop banyak di pakai berbagai kalangan untuk kemudahan pembelanjaan produk kebutuhan mereka secara maya.. Hal ini dikarenakan di dunia Onlineshop berbagai kemudahan transaksi interaktifnya dari proses barang dikirim sampai diterima konsumen terutama seiring kerapkali diadakannya berbagai sale dan discount,. Terbukti dengan berbagai penelitian yang menunjukkan trend pembelanjaan di dunia online Indonesia semakin meningkat dari tahun ke tahun ( $w w w$. Jakpat.net).

Batik dan tenun merupakan salah satu potensi terbesar ekonomi di Indonesia yang dimotori oleh para pengrajin lokal. Buktinya di tahun 2015, batik, tenun, dan kerajinan daerah turut mendorong pertumbuhan industri kreatif hingga Rp.642 trilliun atau 71,1 persen dari total Produk Domestik Bruto (PDB) Indonesia (www.id.techinasia.com).

Ciewie Batik merupakan salah satu Onlineshop BatikdiIndonesiasaatiniyangsejak awal berdiri tahun 2008 senantiasa memiliki Coorporate Vision untuk memperbesar lini bisnisnya dengan menghadirkan berbagai inovasi Interaktif Onlinenya. Memasuki tahun 2016, Ciewie Batik yang dominannya bisa dilihat di akun instagramnya @Ciewiebatik telah membuka beberapa Outlet di wilayah Surabaya. Semua langkah ini tentunya tidak terlepas dari berbagai strategi komunikasi pemasaran interaktifnya dalam meningkatkan dan menjaring konsumen dari semua lapisan serta memperluas ekspansi bisnisnya.

Berbagai dinamika dan menjamurnya E-Commerce dan Onlineshop di Indonesia telah membawa dampak positif bagi ekonomi kreatif Indonesia (www.Bisnisupdate.com). Pada penelitian ini, fokus ditujukan pada Ciewie Batik dalam menjalankan berbagai komunikasi pemasaran interaktif yang sudah menjadi Code of Conduct dalam meng-engage dengan konsumennya sehingga semakin meningkatkan performa Ciewie Batik dalam menjaga Good Reputation dan Good Image bisnisnya di dunia Batik secara omnichannel baik mobile, Online maupun Offline.

Kontribusi penjualan dari akun Instagram Ciewie Batik selama Januari sampai Desember 2017 menunjukkan peningkatan dan pertumbuhan penjualan yang positif

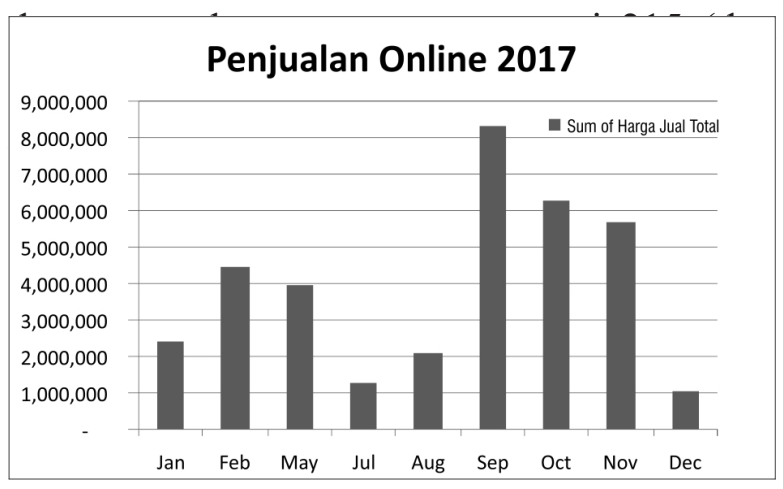

Grafik 1.1

Grafik Penjualan Januari - Desember 2017 (Sumber : Ciewie Batik)

Sesuai dengan uraian fenomenanya maka dapat di tarik pertanyaan penelitian ini yaitu: Bagaimana Strategi komunikasi pemasaran Interaktif Ciewie Batik dalam customer engagement, sehingga tujuan penelitian ini yaitu ingin menunjukkan pemahaman tentang Strategi dan bentuk-bentuk komunikasi pemasaran Interaktif Ciewie Batik dalam melaksanakan bisnisnya. 


\section{KERANGKA TEORI}

\section{Komunikasi Pemasaran}

Everett M. Rogers dan Lawrence Kincaid menyatakan bahwa komunikasi adalah "suatu proses dimana dua orang atau lebih membentuk atau melakukan pertukaran informasi antara satu sama lain, yang pada gilirannya terjadi saling pengertian yang mendalam (Wiryanto, 2008: 6).

Menurut Philip Kotler, pemasaran adalah proses sosial dan manajerial yang di lakukan oleh seseorang atau kelompok untuk memperoleh yang mereka butuhkan dan inginkan melalui penciptaan dan pertukaran produk dan nilai (Suyanto, 2004: 1).

Jadibisa disimpulkan bahwa komunikasi pemasaran adalah suatu proses dimana terdapat dua orang atau lebih yang saling melakukan pertukaran informasi dalam proses sosial dan manajerial untuk memperoleh yang diinginkan melalui penciptaan dan pertukaran produk dan nilai.

Komunikasi dalam era sekarang bukan lagi "360 marketing communications" yang ditujukan kepada komunitas. Namun, menjadi apa yang disebut sebagai "The Matrix" yang ditujukan kepada tiap-tiap individu (Mussry, 2007: 231). "The Matrix" ini adalah sebuah dunia yang dibangun berdasarkan aspirasi pelanggan. Komunikasi pemasaran yang disusun harus bisa menjawab pertanyaanpertanyaan seperti: "who do they think they are", "what they think they are doins", "what they want to be", dan sebagainya. Yang harus diperhatikan, dalam "The Matrix" ini pelanggan tidak dapat berdiri sendiri. Komunikasi yang dijalankan selain harus bisa membuat pelanggan berinteraksi dengan perusahaan juga harus membuat pelanggan bisa berinteraksi satu sama lain (Mussry, 2007: 232).

Dalam rutinitasnya, Ciewie Batik menjalankan komunikasi pemasaran yang sifatnya interaktif dengan konsumennya sehingga tercipta interaksi dua arah dengan pelanggan dalam upaya menginformasikan berbagai penawaran produk.

\section{Social Information Processing Theory}

Social Information Processing Theory menurut Walther (Griffin, 2011) menerangkan sebagai perspektifalternatif dalam memandang fenomena pengembangan hubungan dalam format computer mediated communication. Seiring derasnya perkembangan teknologi komunikasi, format Computer mediated communication dianggap sebagai alat yang kurang berguna untuk mengejar tujuan-tujuan sosial karena memiliki lebih sedikit saluran untuk berinteraksi bila dibandingkan dengan interaksi secara tatap muka (face-to-face) yang menyediakan banyak saluran untuk berinteraksi. Saat ini, Walter mengakui bahwa banyak bentuk-bentuk baru dari komunikasi secara online, seperti situs jejaring sosial (social networking), yang tidak memiliki keterbatasan seperti computer mediated communication.

Social Information Processing menggunakan isyarat verbal dan isyarat temporal sebagai pengaruhutama terhadap pembentukan hubungan. Teori ini menggunakan kedua set isyarat tersebut sebagai parameter di mana komunikasi dan teknologi dapat bergabung 
untuk menghasilkan hubungan impersonal, interpersonal dan hipersonal. Teori ini mengasumsikan bahwa komunikator akan termotivasi untuk membangun hubungan online karena alasan mereka secara pribadi. Namun dalam perkembangannya, dapat diidentifikasi faktor-faktor yang meningkatkan dorongan motivasi untuk membangun hubungan online, yaitu: (1) antisipasi interaksi berikutnya di masa depan dan (2) skeptisisme. Interaksi masa depan diduga mengacu pada prospek bahwa komunikator yang bertemu secara online akan terus memiliki kontak ke masa depan. Komunikator yang mengharapkan kontak dengan mitra mereka di masa depan lebih mungkin untuk bertukar pesan lebih banyak dan membangun hubungan, daripada yang tidak mengharapkan kontak di masa depan. Sedangkan skeptisisme mengacu pada sikap komunikator terhadap penggunaan computer mediated communication untuk membangun persahabatan. Komunikator yang kurang skeptis membentuk lebih banyak persahabatan online, dibandingkan dengan yang memiliki level skeptisime yang tinggi (Littlejohn dan Foss, 2009)

Semua Proses Pemasaran Interaktif yang dilakukan Ciewie Batik sebagai Onlineshop yang melibatkan interaksi yang mayoritas diwujudkan dalam smartphone dengan calon konsumennya sesuai dengan esensi dari Teori Proses Informasi Sosial yang dikemukakan Walter.

\section{Strategi Komunikasi Interaktif}

Strategi adalah keseluruhan keputusan kondisional tentang tindakan yang akan dijalankan guna mencapai tujuan. Dalam merumuskan strategi komunikasi, selain diperlukan perumusan tujuan yang jelas, juga terutama memperhitungkan kondisi dan situasi khalayak (Arifin, 1994).

Internet merupakan salah satu media komunikasi massa yang mempunyai sifat interaktif, di mana khalayak pada medium internet dapat memberikan respon pada sebuah pesan yang tersaji secara langsung. Interaktivitas merupakan komunikasi antara dua orang manusia yang dalam satu waktu memiliki peran ganda yaitu menjadi komunikator sekaligus dapat bertukar peran menjadi komunikan. Komunikasi seperti ini disebut komunikasi interaktif.

Komunikasi interaktif ini menjadikan komunikasi yang dilakukan seseorang atau sekelompok orang, badan atau organisasi lebih efektif. Satu penelitian yang dilakukan oleh McMillan dan Downes pada tahun 1998 (Tankard dan Werner, 2011: 448) mengidentifikasi bahwa terdapat enam dimensi interaktivitas yaitu menginformasikan, kontrol tinggi, aktivitas tinggi, waktu fleksibel, dua arah, serta kesadaran terhadap tempat tinggi.

Riel (2000, 132) dalam Strategic Corporate Communication mengkategorikan Media dan instrumen komunikasi Interaktif berdasarkan interaktivitas dan derajat koneksinya sebagai berikut:

1. Interaktif One-to-One meliputi: Penjualan personal, Telemarketing, Email personal, Konsultan, Website personal, dan Percakapan 
2. Interaktif One-to-Many meliputi: Software/Aplikasi/ CD ROM, Email grup, Humas, Website Umum, Konsultasi

Jadi Strategi komunikasi interaktif merupakan keseluruhan keputusan kondisional tentang tindakan komunikasi Interaktif Oneto-One maupun One-to-Many di media online Internet yang akan dijalankan guna mencapai tujuan bisnis

Ciewie Batik dalam menjalankan kegiatan rutinitas berbisnis yang sudah menjadi Code of Business Conduct dalam menjaga hubungan dengan pelanggan, senantiasa mengacu pada strategi komunikasi Interaktif baik yang One-to-One maupun One-to-Many, yang seakan sudah menjadi Coorporate Guarantee perusahaan terhadap konsumennya sehingga tercipta keberlangsungan dan kesinambungan perusahaan.

\section{Customer Engagement}

Menurut pakar Customer Relationship Management (CRM), Greenberg mendefinisikan customer engagement sebagai "...the ongoing interactions between company and customer, offered by the company, chosen by the customer." A tau dengan kata lain, customer engagement adalah tentang bagaimana membangun interaksi dan keakraban antara suatu perusahaan dengan para konsumennya (2004).

Untuk brand yang masih berkembang dan belum mapan (newcomer brand) dibutuhkan upaya yang lebih besar dalam engagement guna mempertahankan para follower dibandingkan dengan brand yang sudah mapan (established band). Semakin tinggi tingkat customer engagement. Semakin informal dan emosional pula pesan yang disampaikan lewat brand tersebut. Dan customer engagement diketahui memiliki korelasi positif terhadap tingkat penjualan.

Ciewie Batik dalam melaksanakan Komunikasi pemasaran senantiasa memperhatikan aktivitas customer engagement via berbagai instrumen komunikasi interaktif karena komunikasi ini memiliki korelasi terhadap hasil penjualan. Hal ini dikarenakan customer engagement memberikan dampak positif terhadap penjualan batik.

\section{Ciewie Batik}

Ciewie Batik adalah salah satu UKM Batik di Sidoarjo yang didirikan sejak tahun 2008 oleh Pak Widodo yang telah mengalami perkembangan yang sangat pesat. Kini Ciewie Batik telah memiliki beberapa outet cabangnya di wilayah Surabaya. Tidak ketinggalan pula mereka membuka gerai koleksi batik di Carrefour Rangkut Surabaya, Carrefour Ahmad Yani Surabaya, dan Mall City of Tomorrow Surabaya.

Saat ini, produk UKM Pak Widodo ini telah menembus pasar nasional antara lain Timika, Balikpapan, Makasar dan Jakarta. Dalam jangka panjang Ciewie Batik berencana menembus pasar ASEAN.

Penelitian terdahulu penelitian ini dilakukan oleh: Suci Shinta Lestari dengan Judul penelitian: "Strategi Komunikasi Bisnis Lintas Budaya dalam Ekspansi Bisnis (Studi 
pada Radio Eljohn Indonesia)", Program Studi Ilmu Komunikasi Universitas Abdurrab Pekanbaru.

\section{METODOLOGI PENELITIAN}

\section{Pendekatan Penelitian}

Berdasarkan permasalahan yang akan diteliti, pendekatan yang akan digunakan yaitu pendekatan kualititatif. Penelitian komunikasi kualitatif biasanya tidak dimaksudkan untuk memberikan penjelasanpenjelasan (explanations), mengontrol gejala-gejala komunikasi, mengemukakan prediksi-prediksi, atau untuk menguji teori apapun, tetapi lebih dimaksudkan untuk mengemukakan gambaran (description) dan/ atau pemahaman (understanding) mengenai bagaimana dan mengapa suatu gejala atau realitas komunikasi terjadi (Pawito, 2007).

Maksud paling utama dari memberikan gambaran (description) mengenai gejalagejala atau realitas-realitas adalah agar dapat memberikan pemahaman (understanding) mengenai gejala atau realitas. Pemberian pemahaman gejala atau realitas hanya dapat dilakukan oleh peneliti dengan melakukan pembatasan pada kasus dan atau konteks dari gejala atau realitas sehingga hal-hal seperti konsep apa yang digunakan dan apa maknanya serta variabel apa saja yang ada dan bagaimana hubungan antar variabel satu dengan laviabel lainnya baru dapat didefinisikan setelah peneliti melakukan pengamatan, memperoleh data, dan kemudian menganalisisnya. (Pawito, 2007)

\section{Metode Penelitian}

Metode penelitian kualitatif tidak mendasarkan bukti-bukti empirik pada logika statistika matematik, tetapi lebih mendasarkan diri pada hal yang bersifat diskursif, seperti transkrip dokumen, catatan lapangan, hasil wawancara, dokumen-dokumen tertulis. Materi-materi bersifat nondiskursif (seperti candi, patung, monumen, foto, musik, video, gerakan-gerakan), lazimnya dikonversikan ke dalam bentuk narasi yang bersifat deskriptif sebelum dianalisis, diinterpretasi, dan kemudian disimpulkan. (Pawito, 2007)

\section{Obyek Penelitian}

Obyek penelitian di sini yaitu Obyek penelitian di sini yaitu manager pemasaran Ciewie Batik serta para pelanggan Ciewie Batik. Serta penelitian dilakukan di bulan Januari 2018.

\section{Teknik Pengumpulan Data}

Secara garis besar data dalam penelitian kualtatif dapat dikelompokkan menjadi tiga jenis: (a) data yang diperoleh dari interview/ wawancara, (b) data yang diperoleh dari observasi, dan (c) data yang berupa dokumen, teks atau karya seni yang kemudian dinarasikan.

Metode pengumpulan data yang digunakan dalam penelitian ini melalui dokumentasi dan wawancara mendalam.

Dalam penelitian ini, wawancara mendalam yang akan digunakan yaitu dengan manager pemasaran Ciewie Batik serta para pelanggan Ciewie Batik. 
Metode pengumpulan data sekunder yang digunakan dalam penelitian ini yaitu mengkaji beberapa liputan dan dokumentasi tentang Ciewie Batik.

\section{Teknik Analisis Data}

Analisis data kualitatif adalah upaya yang dilakukan dengan jalan bekerja dengan data, mengorganisasikan data, memilahmilahnya menjadi satuan yang dapat dikelola, mensitesiskannya, mencari dan menemukan pola, menemukan apa yang penting dan apa yang dipelajari, dan memutuskan apa yang dapat diceritakan kepada orang lain (Moleong, 2007).

Ada tiga Model Analisis Data((Moleong, 2007) :

1. Model Glaser \& Strauss

2. Model Spradley

3. Model Miles \& Huberman

Dalam penelitian ini, Analisis data kualitatif yang digunakan memakai model Miles \& Huberman. Model ini lazimnya disebut interactive model (Pawito, 2007) . Analisis model ini pada dasarnya terdiri dari tiga komponen yaitu :

\section{Reduksi data}

Meliputi tahapan: (a) melibatkan langkahlangkah editing, pengelompokan dan meringkas data, (b) peneliti menyusun kode-kode dan catatan-catatan (memo) mengenai berbagai hal termasuk yang berkenaan dengan aktivitas serta prosesproses sehingga peneliti dapat menemukan tema-tema, kelompok-kelompok dan pola-pola data.

2. Penyajian data

Melibatkan langkah-langkah pengorganisasian data, yakni menjalin data yang satu dengan data yang lain sehingga seluruh data yang dianalisis benar-benas dilibatkan dalam satu kesatuan.

3. Penarikan serta pengujian kesimpulan.

Mengimplementasikan prinsip induktif dengan mempertimbangkan pola-pola data yang ada dan atau kecenderungan dari display data yang telah dibuat. Ada kalanya kesimpulan telah tergambar sejak awal, namun kesimpulan final tidak pernah dapat dirumuskan secara memadai tanpa peneliti penyelesaikan analisis seluruh data yang ada.

\section{Teknik Pengujian Keabsahan Data}

Teknik Pengujian Keabsahan data dalam penelitian Kualitatif menurut Guba dan Lincoln yaitu dengan menyediakan alternatif reliabilitas dan validitas. Dua kriteria utama untuk menguji penelitian kualitatif adalah Trustworthiness dan Authenticity. Trustworthiness meliputi kredibilitas (credibility), dapat ditransfer (transferability), ketergantungan (dependability), serta konformitas (confirmability) (Kartikawangi, 2013).

Dalam penelitian ini Pengujian Keabsahan data dengan menguji kredibilitas, transferabilitas, ketergantungan, serta konformitas data-data yang didapat dari wawancara mendalam dan dokumentasi. 


\section{HASIL PENELITIAN DAN PEMBAHASAN}

Dalam kegitatan rutin pelayanan pelanggan Ciewie Batik, baik terhadap calon pelanggan maupun pelanggan tetap maka strategi komunikasi pemasaran interaktif yang biasa dipergunakan yaitu: Memaksimalkan serta mengintensifkan akun Instagram @ CiewieBatik dalam upaya menginformasikan koleksi batik baru maupun koleksi batik lama yang diproduksi kembali. Hal ini terkait dengan dimulainya produksi batik cetak (printing) sendiri dari Ciewie batik terhitung tahun 2017. Berdasarkan informasi dari ibu Cindy selaku Manager Pemasaran Ciewie Batik bahwa selain akun Instagram@CiewieBatik, pihak Ciewie Batik juga memperluas jangkauan batik mereka dengan menambahkan dua akun Instagram lainnya yaitu@SupplierFirsthand dan@BatikKejawen. Dan menurutnya,konversi penjualan dari kedua akun ini lumayan bagus.

Selain itu, untuk pelayanan delivery produk ke Pelanggan, pihak Ciewie Batik mengintegrasikan proses ini dengan aplikasi marketplace Shopee di Android. Hal ini dikarenakan aplikasi ini menawarkan free ongkir manakala nominal pembelanjaan dari pelanggan Ciewie Batik menyentuh angka Rp. 125.000,- (seratus dua puluh lima ribu rupiah). Managemen E-Commerce Shopee memberlakukan ketentuan free ongkir untuk semua onlinestore serta pelaku UKM yang bersedia bekerjasama dengan mereka dalam rangka meramaikan Shopee. Berdasarkan wawancara dengan Ibu Maya selaku salah seorang pembeli Ciewie Batik yang merasa free ongkir ini sangat menarik baginya dikarenakan mengefisienkan pembelanjaan dia di dunia maya. Yang mana awalnya dia iseng saja melakukan search di google untuk keperluan batiknya dan dari beberapa vendor batik yang ada beliau merasa tertarik dengan Ciewie Batik karena free ongkir yang ada di Shopee. Begitu juga dengan ibu Cindy selaku Manager Pemasaran Ciewie Batik yang merasakan benefit dari aplikasi Shopee ini sehingga managemen Ciewie Batik bisa memanfaatkan ex-biaya yang tadinya buat ongkir ini untuk biaya promo lainnya.

Pihak Ciewie Batik senantiasa mengintensifkan layanan keluhan ataupun pertanyaan pelanggan (termasuk weekend) serta pelayanan tanggap yang sifatnya express dengan maksimal satu minggu penyelesaiannya (dari tempo di terimanya keluhan pelanggan) di era digital yang highlymobile ini. Menurut ibu Cindy, Pelayanan pelanggan termasuk weekend ini merupakan salah satu pelayanan Ciewie Batik untuk melayani pelanggan setiap saat dalam upaya antisipasi terhadap kompetitor produk batik sejenis yang sekarang sangat kompetitif. Serta pelayanan ini didukung dengan satu nomor Whatsapp yang merupakan hotline pelanggan Ciewie Batik yang biasa dipegang oleh staf marketing. Hotline pelanggan Whatsapp ini difungsionalisasikan untuk keluhan yang sifatnya offline maupun online. Selain itu, aspek komunikasi interaktif yang lain yang dominan juga diterapkan oleh Ciewie Batik yaitu secara rutin dua bulan sekali akan memfollow up pelanggannya untuk menanyakan terkait batik yang sudah dibelinya serta 
mengirimkan motif serta promo terbaru Ciewie Batik. Hal ini merupakan salah satu upaya Ciewie Batik menjemput bola atas semua komplain interaktif dari pelanggan termasuk upaya persuasif untuk mengingatkan pelanggan manakala .ada peluncuran motif batik baru ataupun promo lainnya. Semua pelayanan ini dilakukan Ciewie Batik dalam upaya menjaga komunikasi interaktif dengan pelanggan sehingga tercipta suatu relationship yang empatik dan sustainable. Komunikasi interaktif yang dilakukan Ciewie Batik ini yang dengan melibatkan berbagai komponen perusahaannya yang terkoneksi dengan pelanggan, secara tidak langsung merepresentasikan teori komunikasi Interaktif One-to-One yang disampaikan Riel (2000) dalam Strategic Corporate Communication.di kancah dunia bisnis dewasa ini yang sifatnya always-connected .

Salah seorang informan penelitian ini Bpk Stephen menyampaikan kalau beliau mengenal Ciewie Batik dari Fanpage Facebook Ciewie Batik yang mana dalam satu kesempatan beliau berselancar di Facebook ada muncul Fanpage Ciewie Batik di salah satu tautan pertemanannya. Beliau sempat beberapa kali memesan Ciewie Batik karena batiknya yang model kontemporer sesuai dengan gaya zaman sekarang serta berasal dari Sidoarjo yang merupakan ladangnya Batik Jatim. Ibu Cindy dalam kesempatan wawancara sempat menyinggung soal digunakannya Facebook sebagai salah satu media sosial Ciewie Batik dikarenakan trend penggunaan media ini terutama di Indonesia sangat booming serta disukai kalangan anak muda sekarang ini termasuk begitu viralnya informasi di media ini. Tentunya Ciewie Batik tidak mau ketinggalan untuk memanfaatkan peluang ini apalagi trend pembelanjaan online dari medsos ini semakin meningkat animonya dari tahun ke tahun. Beliau sharing kalau Facebook akan diupayakan semakin intensif pemakaiannya dalam merespons berbagai tanggapan publik baik yang terkait dengan existing customer Ciewie Batik maupun calon pelanggan baru. Umumnya semua respon ini disampaikan dari mereka ke inbox Messager Facebook. Selain itu, Ibu Cindy dan Ownernya Ciewie Batik Pak Widodo selalu menganggap media sosial Facebook ini - khususnya Fanpage Facebook - yang jika dijalankan dengan teknik dan pengoperasian yang konsultatif maka akan mengedukasi pasar dan bukan semata-mata untuk jualan Batik saja, sehingga secara tidak langsung menjadi solution approach bagi pelanggan. Semua komunikasi interaktif Facebook ini juga termasuk dengan memaksimalkan penggunaan fasilitias terupdate dari Facebook yaitu Paidservice dan Background-Coloring. . Semua langkah di media sosial Ciewie Batik ini merupakan komunikasi interaktif yang dikombinasikan dari model Interaktif One-to-One dan One-to-Many seperti yang dikemukakan Riel (2000) dalam Strategic Corporate Communication.

Dalam wawancara Ibu Cindy sempat menginformasikan kalau untuk saat ini perusahaan senantiasa berupaya melebarkan sayapnya secara online untuk mempermudah calon pembeli yang di era ConnectedGeneration ini yang sangat kental dengan 
nuansa apps-dependent. Untuk itu perusahaan tidak mau ketinggalan untuk berpartisipasi di beberapa marketplace seperti Bukalapak.com, Lazada.com, Tokopedia.com dan beberapa merchant marketplace lainnya. Perusahaan juga senantiasa update di website Ciewiebatik. com serta dalam tahap mengembangkan aplikasi berbasis Andorid Ciewiebatik. Hal ini dilakukan untuk mempermudah konversi dan repetisi pembelian batik dari para Neo-millenial Generation ini yang senantiasa berinteraktif multi-media.. Semua Inovasi ini sengaja diciptakan untuk menunjang breakthroughvalue ke konsumen dan calon konsumen sehingga tercapai Good image, Sustainable development dan mutual partnership.

Dari hasil penelusuran di internet terkait seberapa viralnya brand Ciewie Batik maka penulis mendapatkan ternyata dalam menjaga business-continuity perusahaan, pihak Ciewie Batik menggaet beberapa web-reseller sebagai ajang mereka menitipkan batiknya. Web-reseller ini meliputi merchant seperti : Berbatik.com, Priceza.co.id, Naradha. com, GrosirBatikModern.com, Inikebayalho. blogspot.com, BatikAdhity.com dan Qlapa. com. Informasi dari Ibu Cindy membenarkan hal itu, namun menurutnya semua web-reseller ini sifatnya mendukung serta menambah order sekalipun belum begitu signifikan.

Sebagai wujud komunikasi pemasaran interaktif dengan semua pelanggan dan dalam upaya diseminasi informasi batik, maka secara rutin Ciewie Batik mengadakan. talkshow di radio lokal Sidoarjo dan sekitar Surabaya. Termasuk mengisi berbagai kewirausahaan sebagai wujud ekonomi kreatif Ciewiebatik.
Semua ini dilakukan dalam upaya pelaksanaan customer engagement dengan konsumen untuk sustainability relationship.

\section{KESIMPULAN DAN SARAN}

Ciewie Batik dalam menjaga Good Image dan Good Reputation sebagai salah satu vendor Batik di berbagai kalangan senantiasa melakukan berbagai komunikasi pemasaran interaktif baik Online dan offline dengan selalu menekankan kepuasan pelanggan. Semua ini dijalankan dalam upaya menembus market penjualan batik baik domestik maupun mancanegara.

Dalam upaya semakin mendekatkan diri dengan Generasi Milenial yang merupakan Always-connected-Generation dari semua lini kegiatan berbisnis saat ini, maka diharapkan Ciewie Batik semakin berupaya menumbuhkembangkan Value from Innovation yang dengan ini akan mewujudkan komersialisasi kreatifitas yang menunjang perusahaan dalam kerangka customer engagement.

\section{DAFTAR PUSTAKA :}

Arifin, A. (1994). Strategi Komunikasi Sebuah Pengantar Ringkas, Edisi Ketiga, Bandung : CV. Armico.

Greenberg, P. (2004), CRM at the Speed of Light: Essential Customer Strategies for the 21st Century, Third Edition, Singapore : McGraw-Hill.

Griffin, EM. (2004), A First Look At Communication Theory, Fifth Edition, Singapore : McGraw-Hill. 
Kartikawangi, D. (2013), Tema Fantasi, Strategi Komunikasi Bisnis Perusahaan Multinasional, Cetakan Pertama, Jakarta: PT. Gramedia Pustaka Utama.

Littlejohn, S. W. dan Karen A. F. (2009). Teori Komunikasi, Edisi Kesembilan, Jakarta: Penerbit Salemba Humanika.

Pawito, (2007), Penelitian Komunikasi Kualitatif, Edisi Kedua, Yogyakarta: PT. LKIS Pelangi Aksara.

Riel, C.B.M. Van. (2000). Strategic Corporate Communication, Amstendam : Samson Bv.

Suyanto, M. (2007), Marketing Strategy Top Brand Indonesia, Edisi Keempat, Yogyakarta : Penerbit Andi

Tankard, J. W. S. dan Werner J. (2011). Teori Komunikasi (Sejarah, Metode dan Terapan di dalam Media Massa, Jakarta : Kencana.
Wiryanto. (2004), Pengantar Ilmu Komunikasi, Edisi Kedua, Jakarta : Grasindo

\section{Sumber Lain}

Lestari, S.C. (2017). Strategi Komunikasi Bisnis Lintas Budaya dalam Ekspansi Bisnis (Studi pada Radio Eljohn Indonesia). Tesis, Program Studi Ilmu Komunikasi FISIP: Universitas Abdurrab Pekanbaru.

Pertiwi, I. (2016). (http://www.google.co.id/amp/s/ id.techinasia.com/kravasia-berikanalternatif-belanja-batik-secara-online), diakses 5 September 2017.

(2014).(http://www.blog.jakpat.net/hasilinfografis-survey-perilaku-belanjaonline), diakses 30 Agustus 2017.

(2016) (http://www.id.techinasia.com) diakses tanggal 5 Nopember 2017

(2016) (http://www.Bisnisupdate.com) diakses tanggal 5 Nopember 2017 